\title{
Determination of the Best Planting Season for Green Grams in Kitui County, Kenya, Using the Analytic Hierarchy Process
}

\author{
Jane Wangui Mugo ${ }^{1}$, David Kasina Musembi², Patrick Chege Kariuki ${ }^{3}$ \\ 1Department of Earth Sciences, University of Nairobi, Nairobi, Kenya \\ ${ }^{2}$ Department of Geology and Meteorology, South Eastern Kenya University, Kitui, Kenya \\ ${ }^{3}$ Geothermal Training and Research Institute, Dedan Kimathi University of Technology, Nyeri, Kenya \\ Email: *jannymugo@gmail.com
}

How to cite this paper: Mugo, J.W., Musembi, D.K. and Kariuki, P.C. (2021) Determination of the Best Planting Season for Green Grams in Kitui County, Kenya, Using the Analytic Hierarchy Process. Open Access Library Journal, 8: e8156. https://doi.org/10.4236/oalib.1108156

Received: November 5, 2021

Accepted: December 6, 2021

Published: December 9, 2021

Copyright $\odot 2021$ by author(s) and Open Access Library Inc.

This work is licensed under the Creative Commons Attribution International License (CC BY 4.0).

http://creativecommons.org/licenses/by/4.0/ (c) (i) Open Access

\begin{abstract}
Green gram is a short duration crop that is traditionally grown in arid regions and has recently become a flagship value chain crop in Kitui County because of its high economic returns. The purpose of this study was to analyse the spatial variation of rainfall and temperature in the county, and their effects on green gram production. The Analytical Hierarchy Process (AHP) decision making tool was used to determine the perceived weights or influence that rainfall and temperature have on green gram production using information from literature and experts. Seasonal rainfall totals and seasonal mean temperature for the Long rains (March-May; MAM) and Short rains (October-December; OND), were calculated from Worldclim data while the rainfall and temperature requirements for green gram were determined and grouped into four classes based on FAO (1976) guidelines. Using this information the green gram growing potentials were determined and corresponding maps generated. Results of the weighted overlay of rainfall and temperature show that during MAM 4.9\%, 33.9\% and $61.3 \%$ of land in Kitui County are highly, moderately and marginally, suitable for green gram production, respectively. During OND, two classes emerge with $75.6 \%$ and $24.4 \%$ of land in Kitui County being highly and marginally suitable, respectively. Due to the higher potential in OND the farmer with the support of the government should adequately prepare to ensure they maximize on the good environmental conditions.
\end{abstract}

\section{Subject Areas}

Agricultural Science 


\section{Keywords}

Rainfall, Temperature, Green Gram, Analytical Hierarchy Process, Kitui County

\section{Introduction}

The agriculture sector is the largest consumer of weather and climate information worldwide. Solar radiation, precipitation and temperature are the main factors that affect crop growth and therefore productive agriculture is highly dependent on the climatic patterns of a region [1]. Kenya and the Great Horn of Africa (GHA) heavily rely on rain-fed agriculture and water dependent sectors for economic sustainability, and therefore, the population in this region is highly vulnerable to effects of climate variability and climate change [2]. Hence, understanding weather variability and its potential impact on agriculture is key to agricultural development and food security.

The Kitui County government has been promoting green gram (Vigna radiata $L$.) as the most suitable and profitable legume in the County and the Sahelian Solution Foundation (SASOL) and Farm Africa are prominent NGOs working to improve its farming ([3] [4]). Green gram is therefore a priority value chain in the County [5].

Green gram is a short season crop adapted to the multiple cropping systems in the dry and warm conditions of lowland tropics and subtropics. It is a warm season crop that grows in a $20^{\circ} \mathrm{C}$ to $40^{\circ} \mathrm{C}$ temperature range with a $28^{\circ} \mathrm{C}$ to $30^{\circ} \mathrm{C}$ optimum [6] [7] [8]. It requires a mean minimum temperature of $20^{\circ} \mathrm{C}-22^{\circ} \mathrm{C}$ and $350-1000 \mathrm{~mm} /$ annum of rainfall for productive growth [3] [6] [7] [8] with 650 $\mathrm{mm}$ being the optimum (Mutua et al., 1990). Heavy rainfall and cool temperatures increase vegetative growth but decrease pod setting and development [3].

Climatic variability over East Africa has been studied widely and rainfall has been found to exhibit high spatial and temporal variability [9] [10] [11]. Of particular interest is the observation that seasonal rainfall is decreasing [11] [12], which means that the effects of climate change are likely to negatively impact crop yields by the end of the $21^{\text {st }}$ century. [13] [14] studied potential variation of East African rainfall and temperature for the period 1961-2100 and found that both rainfall and temperature were projected to increase during the study period. [15], on the other hand, studied 63 years of rainfall data (1950-2012) for Kenya and found the Short rains had an increasing trend and higher interannual variability than the Long rains while [16] used Harmonic analysis of geographical changes of rainfall seasonality over East Africa using pentad rainfall data for 36 stations for the period 1962-2006 and found that the seasonality of rainfall over the whole region does not follow the classical scheme of north-south pattern with bimodal (unimodal) dominance in areas in the vicinity (north/south) of the equator.

Understanding the spatial variation of climatic parameters and their relation- 
ship with crops can help to combat poverty and hunger by enhancing agricultural and natural resource management, making it possible to improve the socio-economic well-being of smallholder farmers [17]. The Analytic Hierarchy Process (AHP) is a well-established decision-making tool that uses pairwise comparison to measure a decision maker's preference between two parameters based on their real time importance [18] [19] [20] [21]. AHP was introduced by [22] and is one of the fastest growing decision-analysis techniques [23] [24] that can be used to compare the relative importance of rainfall and temperature.

[25] reviewed land suitability studies for green gram production in Kitui County but found no study showing the best season for growing green gram. The aim of this study was to determine how rainfall and temperature varied during the two rainfall seasons in the County, the Long rains which come in March-May (MAM) and the Short rains which come in October-December (OND), and their potential for green gram production. The findings of this work would be beneficial to farmers in zoning and timing of green grams for increased productivity and the County and national governments for development of relevant policy. In addition, because green grams attract international trade, the findings would be of interest to investors who would be interested in supporting farmers or engaging in trade on the product.

\section{Material and Methods}

\subsection{Study Area}

Kitui County (Figure 1) is located in lower eastern Kenya, $150 \mathrm{~km}$ east of Nairobi. It has an area of $30,497 \mathrm{~km}^{2}$ of which $690 \mathrm{~km}^{2}$ is in the Tsavo East National Park [26].

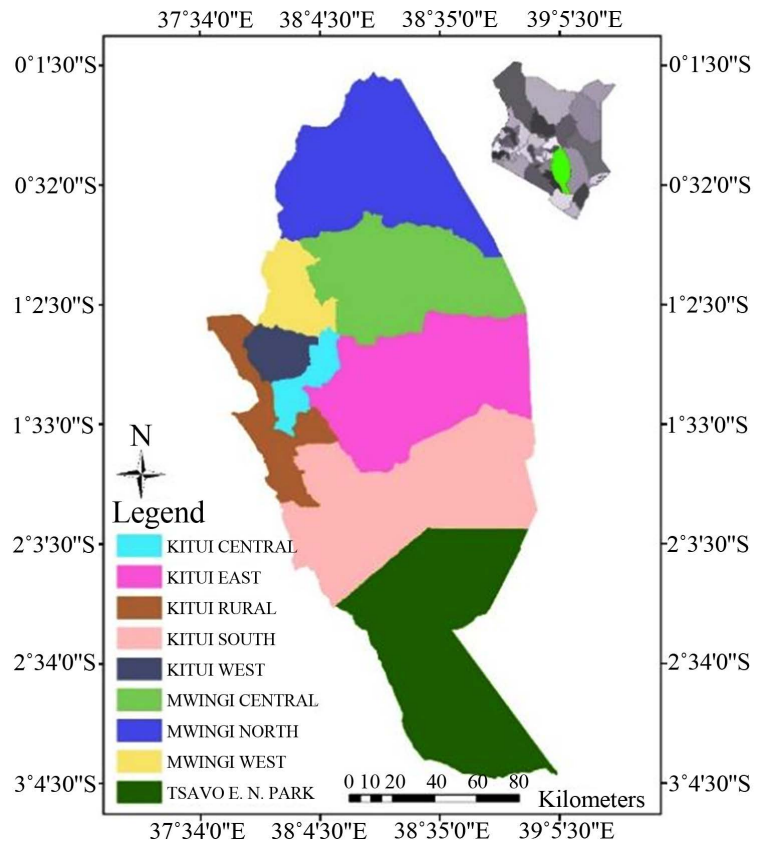

Figure 1. Map of Kitui County, showing Sub Counties and national park. 
Being semi-arid, Kitui County is highly vulnerable to the effects of drought. The periods June to September and January to February are usually dry. The rainfall is bimodal with an annual mean of $750 \mathrm{~mm}$ that varies from 500 to 1050 mm with $40 \%$ reliability and annual mean temperature range between $25^{\circ} \mathrm{C}$ and $30^{\circ} \mathrm{C}[27]$.

\subsection{Methodology}

\subsubsection{Model Input Preparation}

Green gram is a rainfed crop in Kitui County and rainfall and temperature are the climatic factors with greatest impact on production in the County. Monthly rainfall and temperature data were obtained from Worldclim for the period 1950-2000. This time period was used because it has been widely studied in the past ([13] [14] [15] [16]). Data layers in the website were generated through interpolation techniques of mean monthly climate data from several weather stations on a 30 arc-second resolution grid [28] and according to [29], the data from which Worldclim extracts data for Kenya are 736, 708 and 61 stations for mean, minimum and maximum temperature and rainfall.

The seasonal MAM and OND rainfall totals for each year were calculated by adding the rainfall in the corresponding three months while the MAM and OND mean temperature were determined by computing the average temperature for the three respective months. The data was then extracted, geo-referenced and reclassified into 4 suitability classes in a process summarized in Figure 2.

\subsubsection{Suitability Table for Green Gram}

The suitability of Kitui County for growing green gram, based on climatic factors, was summarized into four classes: highly suitable (S1), moderately suitable (S2), marginally suitable (S3) and not suitable (N). These classes are shown in Table 1, which is based on [30] guidelines for rain fed agriculture and reviewed literature and discussions with crop experts.

\subsubsection{Development of Pair Wise Comparison Matrix}

Rainfall and temperature were compared on a scale of 1 to 9 (Table 2) to describes

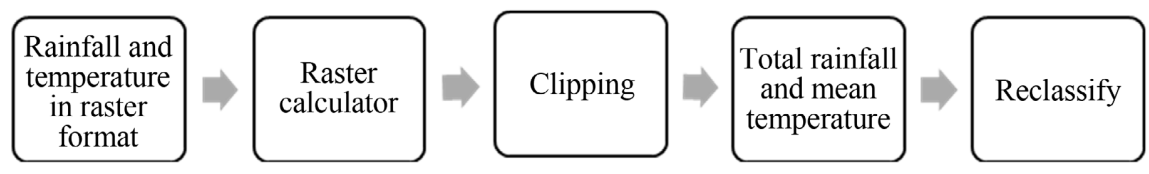

Figure 2. Flow chart for the processing of climate data.

Table 1. Suitability classes for green gram according to FAO [30].

\begin{tabular}{|c|c|c|c|c|c|}
\hline & S1 & S2 & S3 & $\mathrm{N}$ & $\begin{array}{l}\text { Adapted } \\
\text { from }\end{array}$ \\
\hline Rainfall & $350-600 \mathrm{~mm}$ & $\begin{array}{c}600-1000 \mathrm{~mm} \\
\text { or } \\
300-350 \mathrm{~mm}\end{array}$ & $\begin{array}{l}>1000 \mathrm{~mm} \text { or } \\
230-300 \mathrm{~mm}\end{array}$ & $<230 \mathrm{~mm}$ & [31] \\
\hline Temperature & $30^{\circ} \mathrm{C}-24^{\circ} \mathrm{C}$ & $24^{\circ} \mathrm{C}-20^{\circ} \mathrm{C}$ & $20^{\circ} \mathrm{C}-15^{\circ} \mathrm{C}$ & $<15^{\circ} \mathrm{C}$ or $>30^{\circ} \mathrm{C}$ & [6] [7] [8] \\
\hline
\end{tabular}


Table 2. The scale of relative importance between two factors.

\begin{tabular}{cll}
$\begin{array}{c}\text { Intensity of } \\
\text { relative } \\
\text { importance }\end{array}$ & \multicolumn{1}{c}{ Definition } & \multicolumn{1}{c}{ Explanation } \\
\hline $\mathbf{1}$ & Equally preferred & Both contribute equally to the objective \\
$\mathbf{3}$ & Weakly preferred & $\begin{array}{l}\text { Experience and logic slightly favor one } \\
\text { factor over another }\end{array}$ \\
$\mathbf{5}$ & Strongly preferred & $\begin{array}{l}\text { Experience and logic strongly } \\
\text { or essentially favor one factor } \\
\text { over another }\end{array}$ \\
$\mathbf{7}$ & Very strongly preferred & $\begin{array}{l}\text { One factor is strongly favored over } \\
\text { another and its dominance } \\
\text { demonstrated in practice }\end{array}$ \\
$\mathbf{9}$ & Absolutely preferred & $\begin{array}{l}\text { The evidence favoring one factor } \\
\text { over the other is of the highest } \\
\text { degree possible }\end{array}$ \\
\hline $\mathbf{4 , 6 , 8}$ & Intermediates values & $\begin{array}{l}\text { Used when compromise between the } \\
\text { factors is needed }\end{array}$ \\
\hline
\end{tabular}

(After: Saaty, 2000).

the intensity of their relative importance [32]. The weights express the importance of each factor relative to the other [19].

\subsubsection{The Consistency Ratio}

AHP calculates the Consistency Ratio (CR) which measures how much variation is allowed for reasonable results and is expected to be less than 10 percent for AHP results to be accepted [33]. The CR is obtained from the Consistency Index (CI) and is determined as shown in Equations (1) and (2);

$$
\begin{gathered}
\mathrm{CI}=\frac{\lambda_{\text {max }}-n}{n-1} \\
\mathrm{CR}=\frac{\mathrm{CI}}{\mathrm{RI}}
\end{gathered}
$$

where $\lambda_{\max }$ is the maximum Eigen value, RI is the Random inconsistency Index and $n$ is the number of criteria or sub-criteria being compared [18] [33]. The $\mathrm{RI}$ is chosen depending on the number of elements being compared as shown in Table 3.

\subsubsection{Green Gram Suitability Map}

The rainfall and temperature maps were rated and reclassified using the AHP and assigned weights which were determined in consultation with crop experts, reflecting the influence of each factor on green gram production. The maps were subsequently overlaid to generate the final output, the green gram suitability map. 
Table 3. Random Inconsistency Indices for $\mathrm{N}=1,2, \ldots, 15$.

\begin{tabular}{cccccc}
\hline $\mathrm{N}$ & $\mathrm{RI}$ & $\mathrm{N}$ & $\mathrm{RI}$ & $\mathrm{N}$ & $\mathrm{RI}$ \\
\hline $\mathbf{1}$ & 0 & 6 & 1.24 & 11 & 1.51 \\
2 & 0 & 7 & 1.32 & 12 & 1.48 \\
$\mathbf{3}$ & 0.58 & 8 & 1.41 & 13 & 1.56 \\
4 & 0.9 & 9 & 1.45 & 14 & 1.57 \\
5 & 1.12 & 10 & 1.49 & 15 & 1.59 \\
\hline
\end{tabular}

Source: [34].

\section{Results and Discussions}

\subsection{Analytical Hierarchy Process Results}

The results of pairwise comparison between rainfall and temperature (Table 4) showed that $67 \%$ of experts consider rainfall more important than temperature (33\%), which is a reflection of the importance of water in the dry lands in limiting crop growth [17] and agrees with past researchers that rainfall is the most important weather parameter in East Africa as the economies of the region are dependent on rain fed agriculture [35] [36].

\subsection{Rainfall Sub-Criteria}

\subsubsection{The MAM Rainfall}

The MAM rainfall varies between $155 \mathrm{~mm}$ and $663 \mathrm{~mm}$ (Figure 3(a)) and the reclassified rainfall map (Figure 3(b)) shows that during this season, $50.4 \%$ of the county has varying degrees of suitability for growing green gram; with $4.9 \%$ having high suitability while $11.1 \%$ and $34.4 \%$ have moderate and marginal suitability, respectively (Table 5). The suitable areas in MAM are in the Central and Western regions of the County and the remaining $49.6 \%$ is unsuitable for green gram production.

\subsubsection{The OND Rainfall}

The OND rainfall varies between $239 \mathrm{~mm}$ and $729 \mathrm{~mm}$ (Figure 4) and the reclassified rainfall map shows that the entire County is suitable for green gram production during this season (Figure 4, Table 6), where $75.6 \%$ of the county is highly suitable while $22.5 \%$ and $1.9 \%$ have moderate and marginal suitability, respectively. The areas of marginal suitability are located in the extreme Northern and Southern part of the County. These results agree with [32] who observed that green gram performs best when rainfall is between $350-600 \mathrm{~mm}$, moderately at $300-350 \mathrm{~mm}$ and $600-1000 \mathrm{~mm}$ and marginally when rainfall is between $230-300 \mathrm{~mm}$.

\subsection{The Temperature Sub-Criteria}

Unclassified maps of MAM and OND show that temperature increases from west to east. Areas of high suitability in both seasons are located in the central 


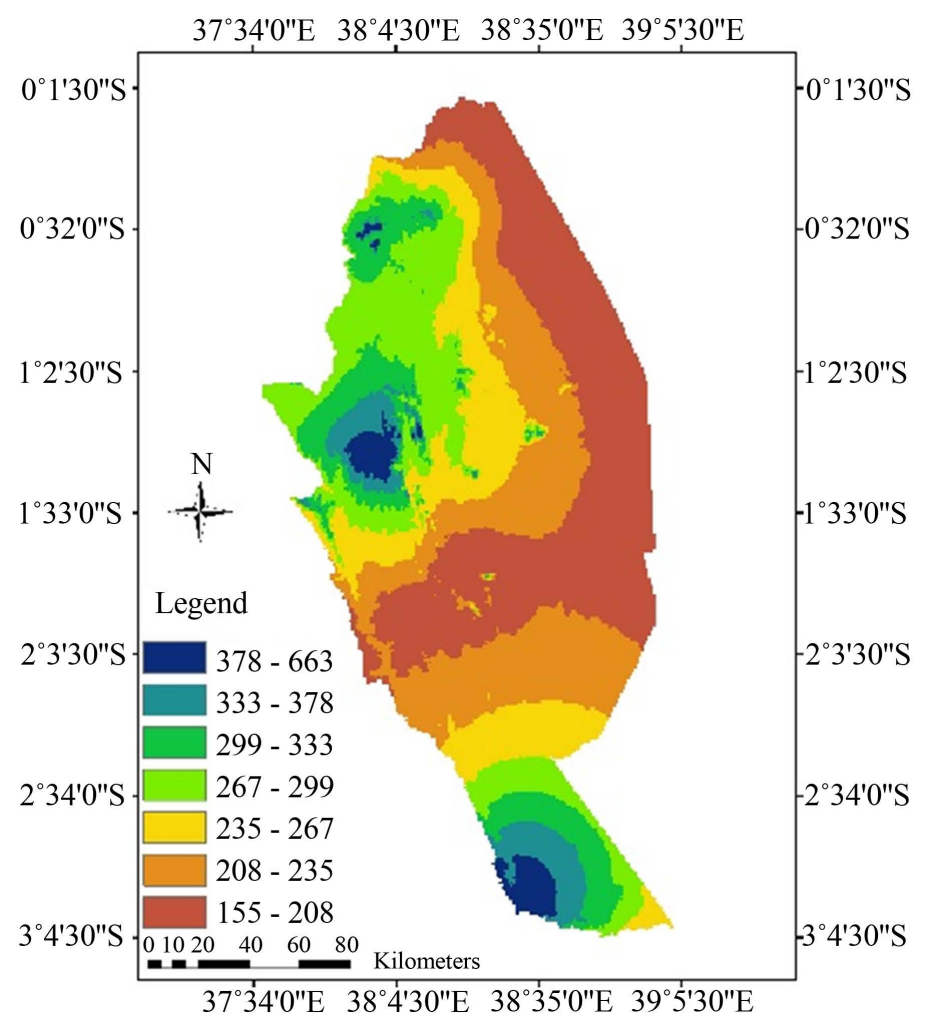

(a)

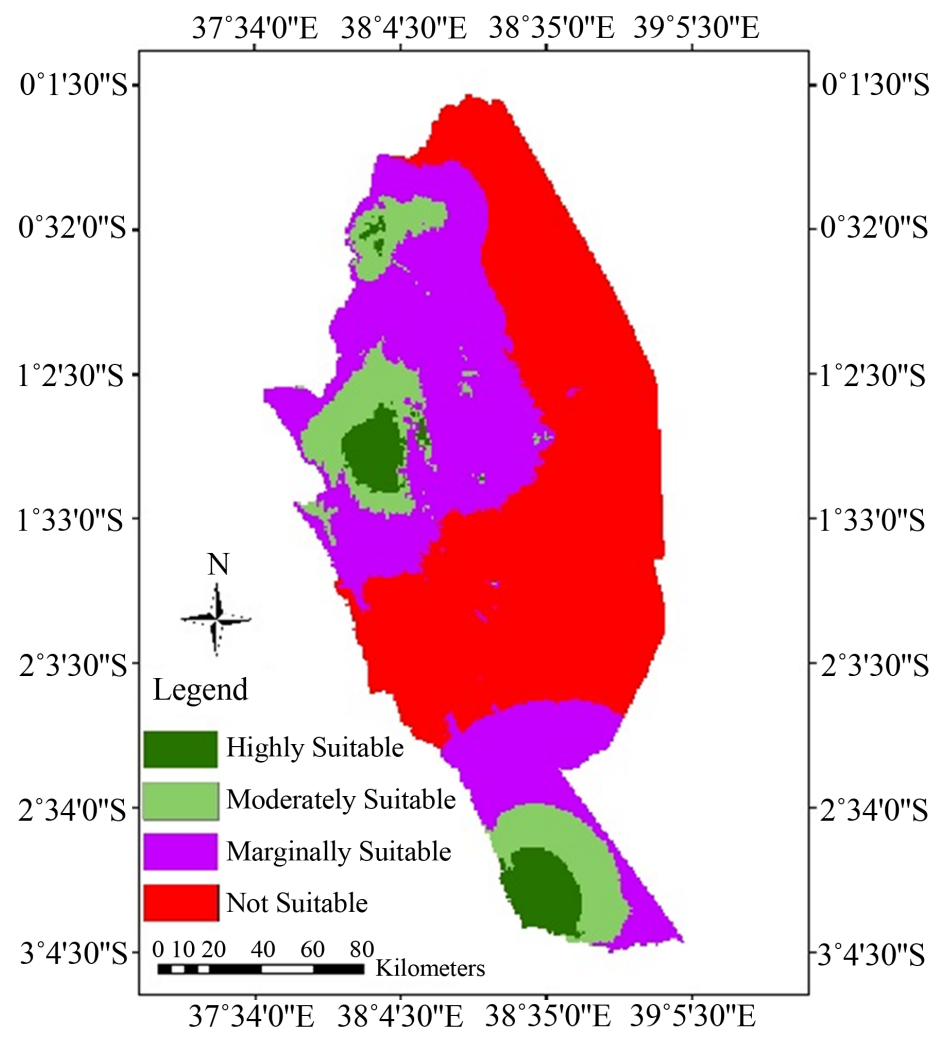

(b)

Figure 3. Unclassified (a) and classified (b) rainfall for Green gram production during the MAM season in Kitui County. 


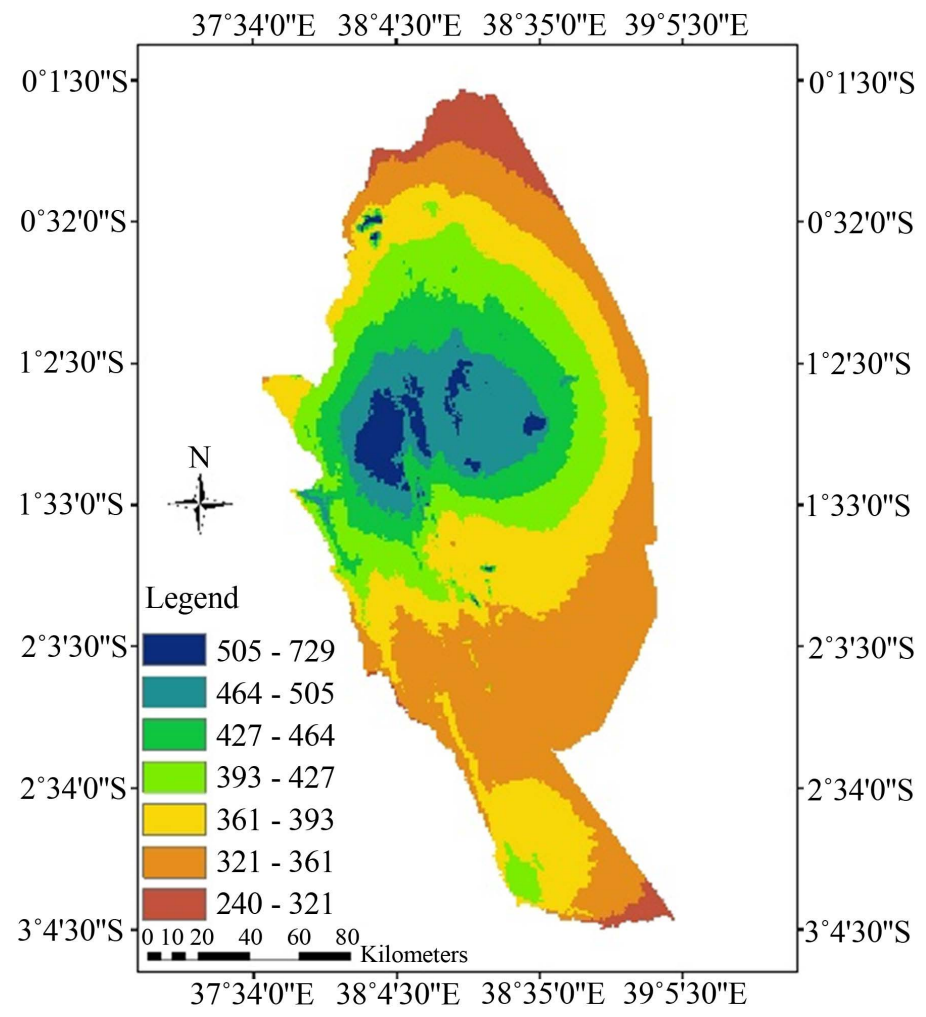

(a)

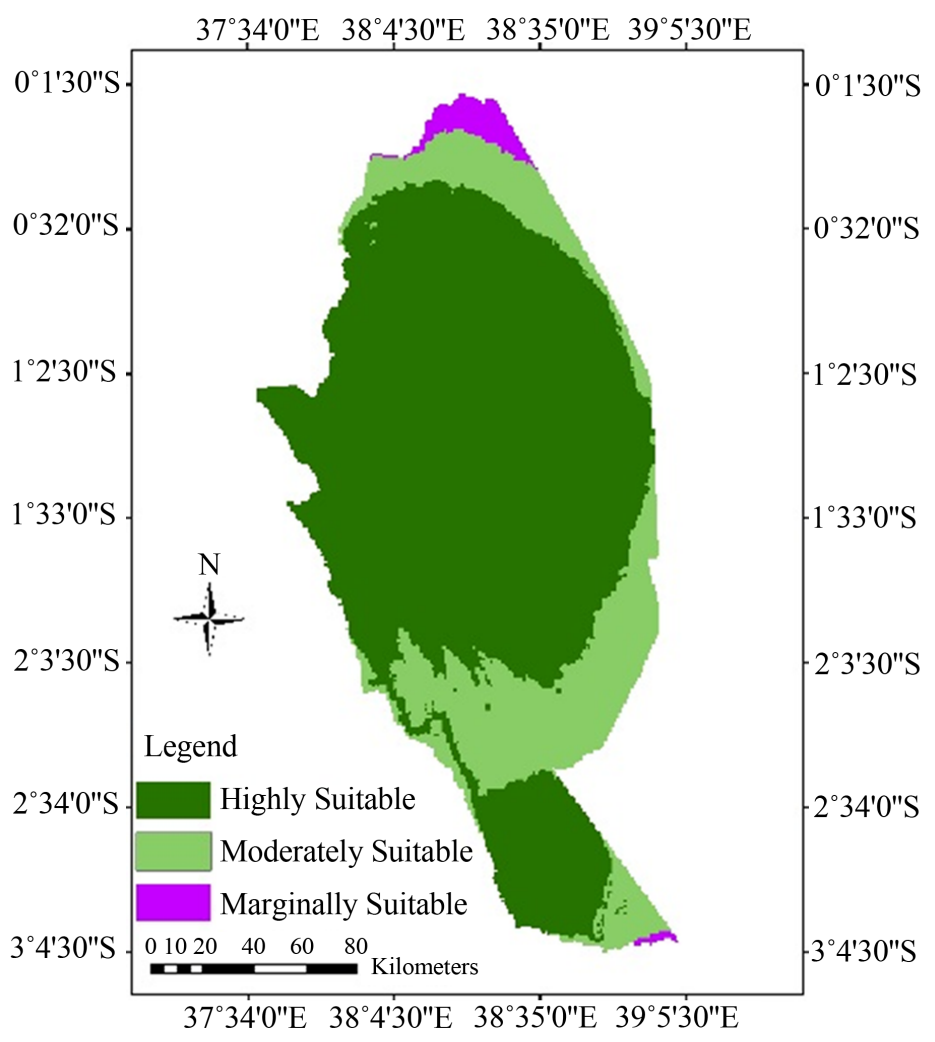

(b)

Figure 4. Map of Kitui County showing unclassified (mm) (a) and reclassified (b) OND Rainfall for Green gram production. 
Table 4. Pairwise comparison results for rainfall and temperature.

\begin{tabular}{ccccc}
\hline & Rainfall & Temperature & Weight & Rank \\
\hline Rainfall & 1 & 2 & 67 & 1 \\
Temperature & 0.5 & 1 & 33 & 2 \\
\hline \multicolumn{7}{c}{$\mathrm{CR}=0 \%$} \\
\hline
\end{tabular}

Table 5. Green gram suitability classes in Kitui County during the MAM rainfall.

\begin{tabular}{cccc}
\hline Suitability class & Rainfall $(\mathrm{mm})$ & Area (Ha) & Area (\%) \\
\hline S1 & $350-600$ & 149,034 & 4.9 \\
S2 & $600-663$ & & \\
S3 & $300-350$ & 339,924 & 11.1 \\
N & $230-300$ & $1,049,925$ & 34.4 \\
\hline
\end{tabular}

Table 6. Suitability classes for green gram production during the OND rainfall in Kitui County.

\begin{tabular}{cccc}
\hline Suitability class & Rainfall $(\mathrm{mm})$ & Area (Ha) & Area (\%) \\
\hline S1 & $350-600$ & $2,311,141$ & 75.6 \\
S2 & $600-729$ & 686,332 & 22.5 \\
S3 & $300-350$ & 57,395 & 1.9 \\
\hline
\end{tabular}

and eastern part of the County (Figure 5 and Figure 6). The suitability analysis shows that in terms of temperature Kitui County falls into two suitability classes for green gram production which are the highly and moderately suitable classes.

\subsubsection{The MAM Temperature}

The MAM temperature varies between $19.1^{\circ} \mathrm{C}$ to $27.4^{\circ} \mathrm{C}$ and the reclassified temperature map shows that during this season $78.68 \%, 21.29 \%$ and $0.03 \%$ of the County has high, moderate and marginal suitability for green gram production (Figure 5, Table 7).

\subsubsection{The OND Temperature}

The OND temperature varies between $18.6^{\circ} \mathrm{C}$ to $26.9^{\circ} \mathrm{C}$ (Figure $6(\mathrm{a})$, Table 8) and after reclassification (Figure $6(\mathrm{~b})$ ), $70.0 \%$ and $30.0 \%$ of the land is highly and moderately suitable for green gram production, respectively. The reduction in the area with potential high productivity compared with MAM could be attributed to the lower temperature during OND. Green grams perform best at a temperature of $30^{\circ} \mathrm{C}-24^{\circ} \mathrm{C}$ and moderately at $24^{\circ} \mathrm{C}-20^{\circ} \mathrm{C}$ [6] [7] [8].

\subsection{The Composite Green Gram Climate Suitability Map}

Since the CR $<10 \%$, the weights attained from AHP were assigned accordingly 


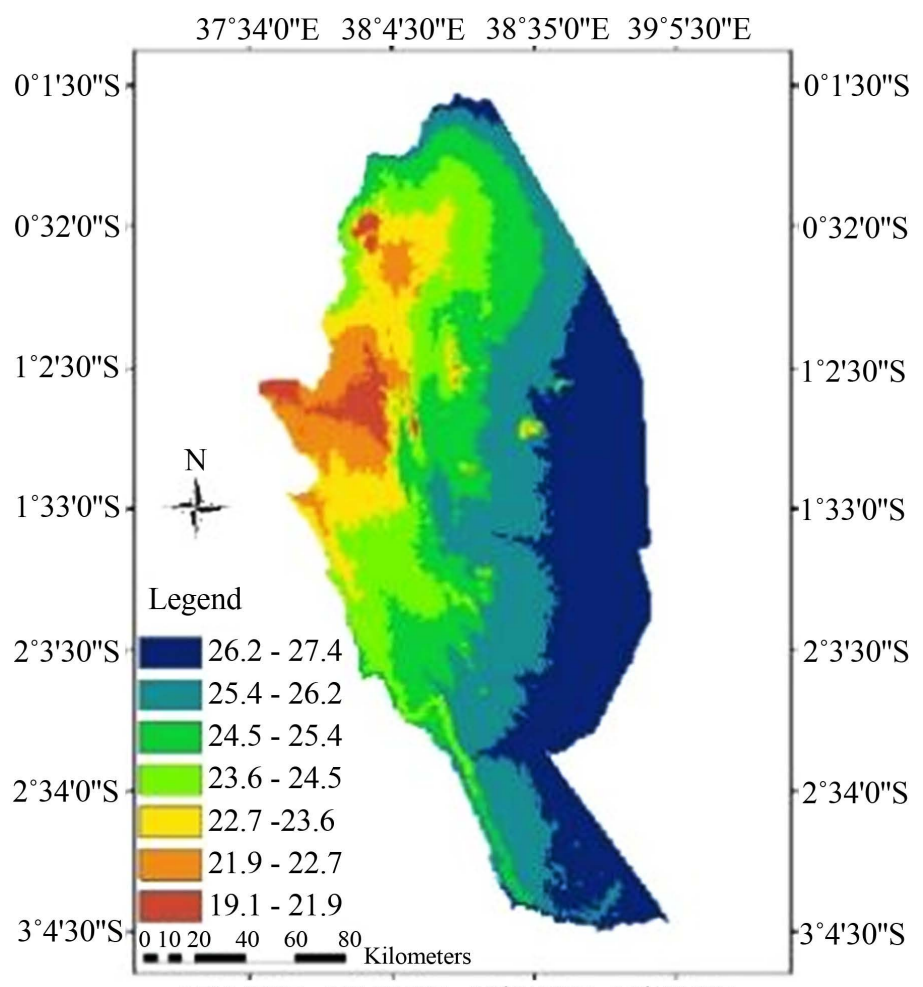

$37^{\circ} 34^{\prime} 0^{\prime \prime} \mathrm{E} \quad 38^{\circ} 4^{\prime} 30^{\prime \prime} \mathrm{E} \quad 38^{\circ} 35^{\prime} 0^{\prime \prime} \mathrm{E} \quad 39^{\circ} 5^{\prime} 30^{\prime \prime} \mathrm{E}$

(a)

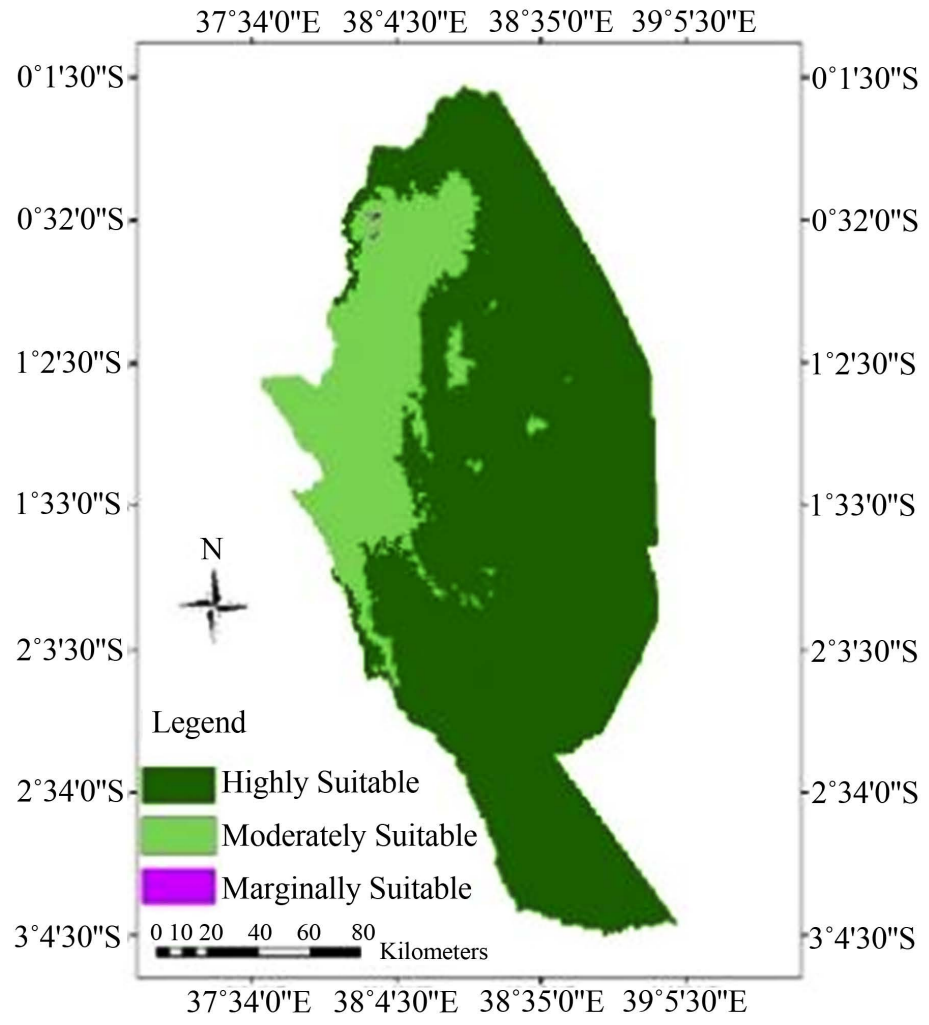

(b)

Figure 5. Spatial variation of MAM temperature (a) and the green gram production potential after reclassification (b) for Kitui County. 


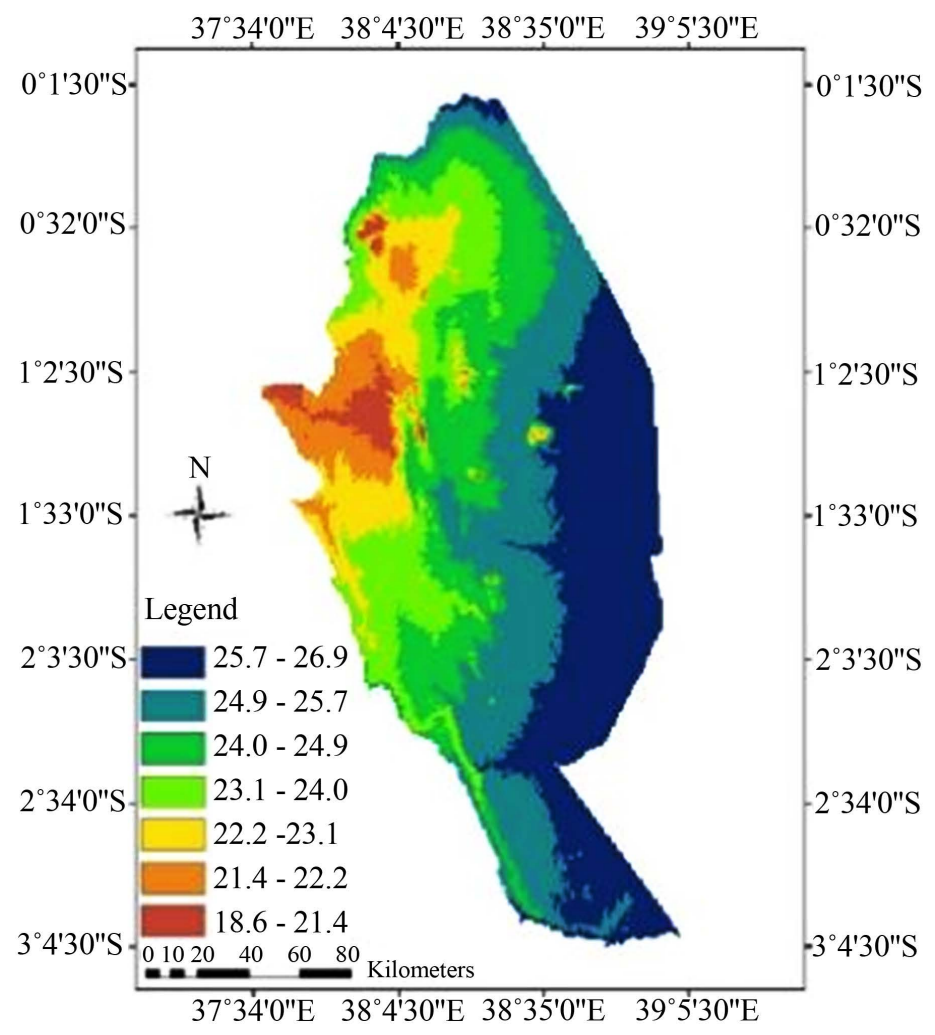

(a)

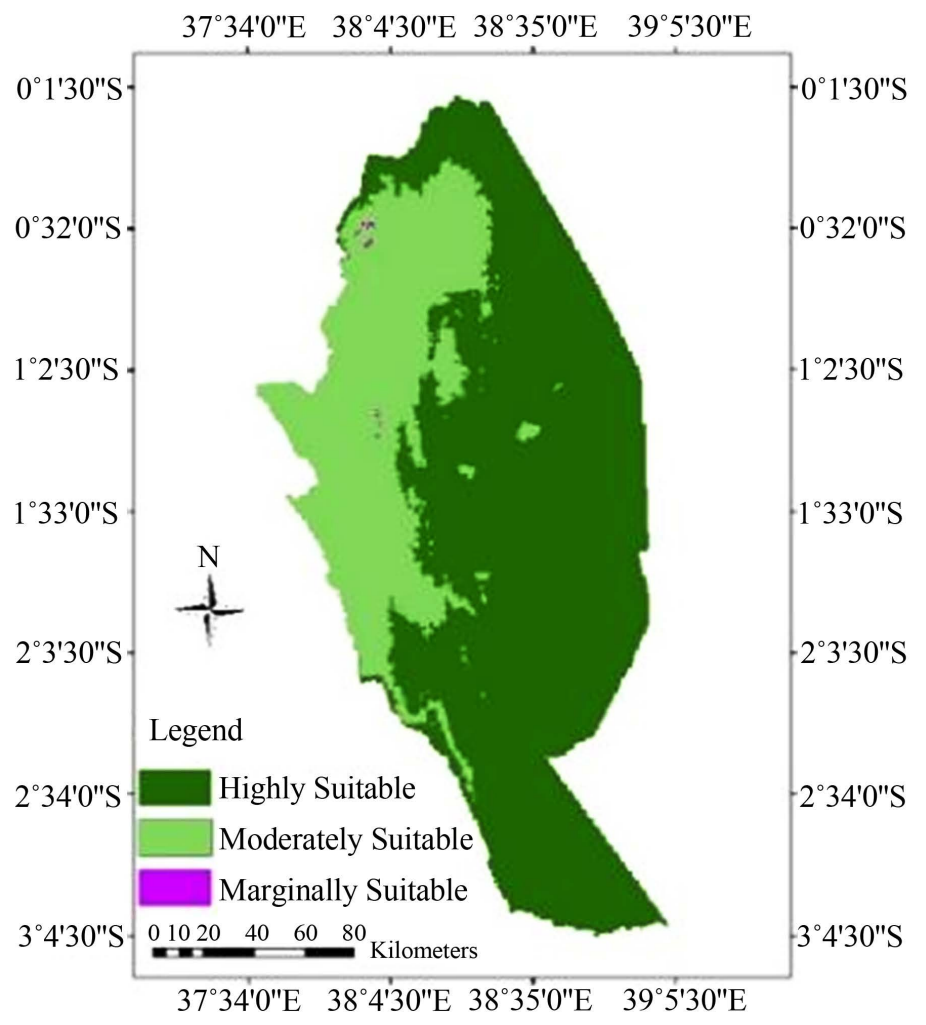

(b)

Figure 6. Spatial variation of OND temperature (a) and the green gram production potential after reclassification (b) for Kitui County. 
(Table 9) and the maps of rainfall and temperature were overlaid to generate composite suitability maps (Figure 7(a) \& Figure 7(b)). During the MAM season, $4.9 \%, 33.9 \%$ and $61.3 \%$ of the land is highly, moderately and marginally suitable for green grap production, respectively. The areas of high suitability are in the west-central part of the County and the extreme south (Figure 7(a)).

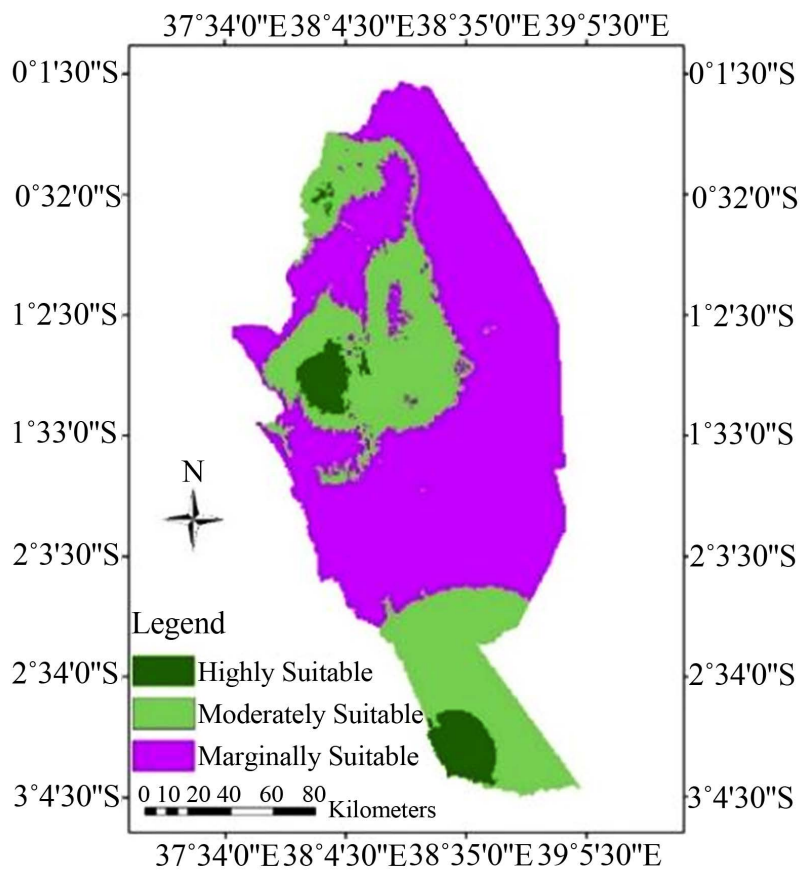

(a)

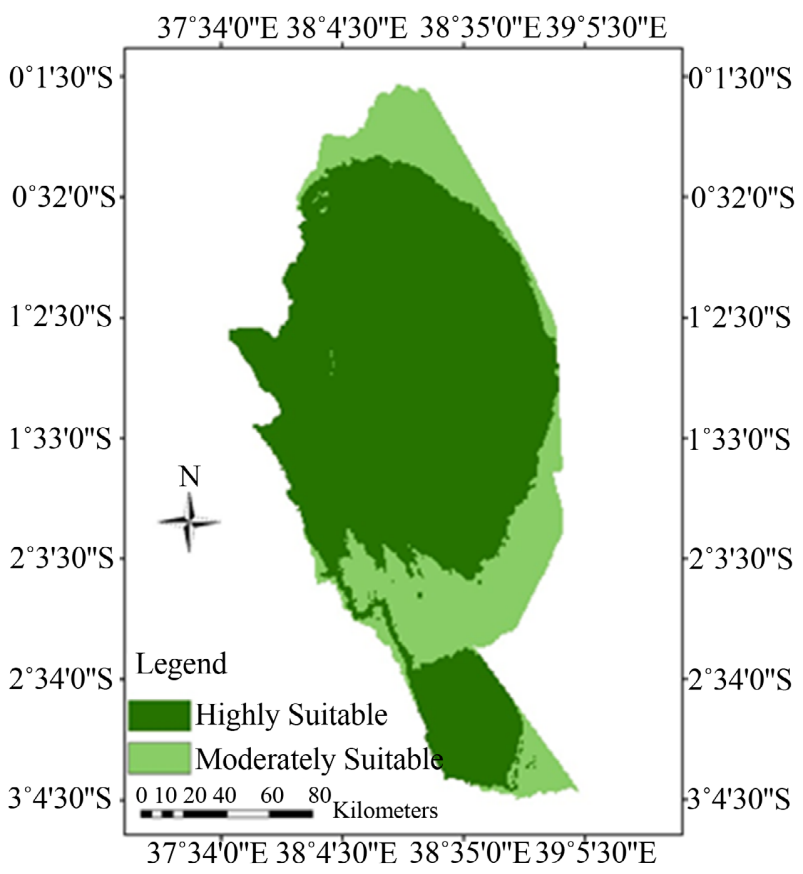

(b)

Figure 7. Composite maps showing green gram production potential during. MAM (a) and OND (b) seasons. 
Table 7. Suitability of green gram production in Kitui County based on temperature during the MAM season.

\begin{tabular}{cccc}
\hline Suitability class & Temperature $\left({ }^{\circ} \mathrm{C}\right)$ & Area (Ha) & Area (\%) \\
\hline S1 & $27.4-24$ & $2,403,452$ & 78.68 \\
S2 & $24-20$ & 650,477 & 21.29 \\
S3 & $20-15$ & 939 & 0.03 \\
\hline
\end{tabular}

Table 8. Suitability of green gram production in Kitui County based on temperature during the OND season.

\begin{tabular}{cccc}
\hline Suitability class & Temperature $\left({ }^{\circ} \mathrm{C}\right)$ & Area (Ha) & Area (\%) \\
\hline S1 & $26.9-24$ & $2,137,857$ & 69.98 \\
S2 & $24-20$ & 915,045 & 29.95 \\
S3 & $20-15$ & 1966 & 0.06 \\
\hline
\end{tabular}

Table 9. Composite green gram production potential during the MAM and OND seasons.

\begin{tabular}{cccccc}
\hline Suitability (MAM) & Area (Ha) & Area (\%) & Suitability (OND) & Area (Ha) & Area (\%) \\
\hline S1 & 148,266 & 4.9 & S1 & $2,309,944$ & 75.6 \\
S2 & $1,035,109$ & 33.9 & S2 & 744,924 & 24.4 \\
S3 & $1,871,493$ & 61.3 & & & \\
\hline
\end{tabular}

During the OND season, $75.6 \%$ is highly suitable while $24.4 \%$ is moderately suitable for green gram production (Figure $7(\mathrm{~b})$ ). The higher suitability in OND over MAM is likely due to higher rainfall during this season and leads to the conclusion that it is the better season to grow green gram in Kitui County. This agrees with [37] conclusion that green gram yield is more dependent on adequate water supply than any other single environmental factor.

\section{Conclusions}

On the basis of temperature, the County is suitable for green gram production during the two seasons; being either highly (78.68\%) or moderately (21.29\%) suitable during MAM and 69.98\% highly and $29.95 \%$ moderately suitable during OND.

The main climatic factor limiting suitability for green gram production in the County was found to be rainfall. The OND season has higher potential for green gram production compared to the MAM season, with $75.6 \%$ of the County being highly and $24.4 \%$ moderately suitable during OND while $4.9 \%$ and $33.9 \%$ of the county has high and moderate suitability, respectively, during MAM. The remaining $61.3 \%$ of the County in MAM has marginal suitability due to inadequate rainfall. 


\section{Acknowledgements}

The first, second and third authors wish to thank South Eastern Kenya University for enabling them to conduct the research.

\section{Conflicts of Interest}

The authors declare no conflicts of interest.

\section{References}

[1] Hossain, M.A. (2010) Global Warming Induced Sea Level Rise on Soil, Land and Crop Production Loss in Bangladesh. 19th World Congress of Soil Science, Soil Solutions for a Changing World, Brisbane, 1-6 August 2010, 77-80. https://www.iuss.org/19th\%20WCSS/Symposium/pdf/0419.pdf

[2] IPCC (Intergovernmental Panel on Climate Change) (2007) Climate Change 2007: The Physical Science Basis. Contribution of Working Group I to the Fourth Assessment Report of the Intergovernmental Panel on Climate Change [Solomon, S., Qin, D., Manning, M., Chen, Z., Marquis, M., Averyt, K.B., Tignor, M. and Miller, H.L., Eds.]. Cambridge University Press, Cambridge and New York, 996 p.

[3] Sahelian Solution Foundation (SASOL) (2015) Green Grams Hand Book, A Guide to Farmers within Project Enhancing Food Security with Diversified Dry Land Farming Techniques in Kitui County. Sahelian Solution Foundation, Kenya. http://www.sasolfoundation.co.ke/2013/wp-content/uploads/2015/02/Green-Grams -Manual.pdf

[4] Farm Africa (2016) Sorghum and Green Grams. http://www.farmafrica.org/kenya/sorghum-and-green-grams/

[5] Agricultural Sector Development Programme (ASDSP) (2016) Kitui County Profile. http://asdsp.kilimo.go.ke/prioritized-value-chains/

[6] Mogotsi, K.K. (2006) Vignaradiata (L.) R. Wilczek. Record from Protabase. Brink, M. and Belay, G., Eds., PROTA (Plant Resources of Tropical Africa/Ressourcesvégétales de l'Afriquetropicale), Wageningen.

https://www.feedipedia.org/node/14363

[7] Morton, F., Smith, R.E. and Poehlman, J.M. (1982) The Mungbean. The College of Agricultural Sciences, Puerto Rico.

[8] Directorate Plant Production (DPP) (2010) Mung Bean Production Guideline. Directorate Plant Production, Pretoria.

http://www.nda.agric.za/docs/brochures/mbeanpgudelins.pdf

[9] Indeje, M., Semazzi, F.H., Xie, L. and Ogallo, L.J. (2001) Mechanistic Model Simulations of the East African Climate Using NCAR Regional Climate Model: Influence of Large-Scale Orography on the Turkana Low-Level Jet. Journal of Climate, 14, 2710-2724. https://doi.org/10.1175/1520-0442(2001)014\%3C2710:MMSOTE\%3E2.0.CO;2

[10] Anyah, R.O. and Semazzi, F.H.M. (2006) Climate Variability over the Greater Horn of Africa Based on NCAR AGCM Ensemble. Theoretical and Applied Climatology, 86, 39-62. https://doi.org/10.1007/s00704-005-0203-7

[11] Ongoma, V. and Chen, H. (2016) Temporal and Spatial Variability of Temperature and Precipitation over East Africa from 1951 to 2010. Meteorology and Atmospheric Physics, 129, 131-144. https://doi.org/10.1007/s00703-016-0462-0

[12] Yang, W., Seager, R., Cane, M.A. and Lyon, B. (2014) The East African long rains in 
observations and models. Journal of Climate, 27, 7185-7202. https://doi.org/10.1175/JCLI-D-13-00447.1

[13] Adhikari, U., Nejadhashemi, A.P. and Woznicki, S.A. (2015) Climate Change and Eastern Africa: A Review of Impact on Major Crops. Food and Energy Security, 4, 110-132. https://doi.org/10.1002/fes3.61

[14] Ongoma, V., Chen, H. and Gao, C. (2017) Projected Changes in Mean Rainfall and Temperature over East Africa Based on CMIP5 Models. International Journal of Climatology, 38, 1375-1392. https://doi.org/10.1002/joc.5252

[15] Sagero, P.O., Shisanya, C.A. and Makokha, G.L. (2018) Investigation of Rainfall Variability over Kenya (1950-2012). Journal of Environmental and Agricultural Sciences, 14, 1-15.

[16] Owiti, Z. and Zhu, W. (2012) Spatial Distribution of Rainfall Seasonality over East Africa. Journal of Geography and Regional Planning, 5, 409-421. https://doi.org/10.5897/JGRP12.027

[17] Kisaka, M.O., Mucheru-Muna, M., Ngetich, F.K., Mugwe, J.N., Mugendi, D. and Mairura, F. (2015) Rainfall Variability, Drought Characterization, and Efficacy of Rainfall Data Reconstruction: Case of Eastern Kenya. Advances in Meteorology, 2015, Article ID: 380404. https://doi.org/10.1155/2015/380404

[18] Baniya, M. S. N. (2008) Land Suitability Evaluation Using GIS for Vegetable Crops in Kathmandu valley/Nepal. Doctoral Dissertation, Humboldt-Universitätzu Berlin, Berlin.

[19] Lupia, D.F. (2014) Crop/Land Suitability Analysis by ArcGIS Tools. Technical Report.

https://www.researchgate.net/profile/Flavio-Lupia/publication/268517989 CROPL AND SUITABILITY ANALYSIS BY ARCGIS TOOLS/links/546f06830cf2b5fc17 60a8d1/CROP-LAND-SUITABILITY-ANALYSIS-BY-ARCGIS-TOOLS.pdf

[20] Tisza, K. (2014) GIS-Based Suitability Modeling and Multi-Criteria Decision Analysis for Utility Scale Solar Plants in Four States in the Southeast US. MSc. Thesis, Clemson University, Clemson.

[21] Majumder, M. (2015) Impact of Urbanization on Water Shortage in Face of Climatic Aberrations. Springer Verlag, Singapore, 35-47. https://doi.org/10.1007/978-981-4560-73-3

[22] Saaty, T.L. (1977) A Scaling Method for Priorities in Hierarchical Structures. Journal of Mathematical Psychology, 15, 234-281. https://doi.org/10.1016/0022-2496(77)90033-5

[23] Bello, D.A., Farmani, R., Javadi, A.A. and Evans, B.M. (2009) The Analytical Hierarchy Process for Contaminated Land Management. Advanced Engineering Informatics, 23, 433-441. https://doi.org/10.1016/j.aei.2009.06.006

[24] Jafari, S. and Zaredar, N. (2010) Land suitability analysis using multi attribute decision making approach. International Journal of Environmental Science and Development, 1, 441-445. https://doi.org/10.7763/IJESD.2010.V1.85

[25] Mugo, J.W., Kariuki, P.C. and Musembi, D.K. (2016) Identification of Suitable Land for Green Gram Production Using GIS Based Analytical Hierarchy Process in Kitui County, Kenya. Journal of Remote Sensing and GIS, 5, Article No. 170. https://doi.org/10.4172/2469-4134.1000170

[26] Republic of Kenya (ROK) (2009) Agricultural Sector Development Strategy. Ministry of Agriculture, Government Press, Nairobi.

[27] Republic of Kenya (ROK) (2010) National Climate Change Response Strategy. Government Press, Nairobi 
[28] Hijmans, R.J., Cameron, S.E., Parra, J.L., Jones, P.G. and Jarvis, A. (2005) Very high resolution interpolated climate surfaces for global land areas. International Journal of Climatology, 25, 1965-1978. https://doi.org/10.1002/joc.1276

[29] Peter, L., Anton, E. and Oriana, O. (2010) Climate Change Adaptation and Mitigation in the Kenyan Coffee. Cali, Colombia. https://www.ipcc.ch/apps/njlite/ar5wg2/njlite download2.php?id=10114

[30] FAO (Food and Agriculture Organization of the United Nations) (1976) A Framework for Land Evaluation. Soils Bulletin No. 32. Food and Agriculture Organization of the United Nations, Rome.

[31] Takeshi, T. and Ruth, B. (2015, January) Using Climate Information for Supporting mung Bean Plantation over Sumbawa Region. WeADAPT.

https://www.weadapt.org/knowledge-base/climate-adaptation-training/using-climat e-information-for-supporting-mung-bean-plantation-over-sumbawa-region

[32] Saaty, T.L (2000) Fundamentals of Decision Making and Priority Theory with the Analytic Hierarchy Process. No. 6, RWS Publications, Pittsburgh, 21-28.

[33] Dadfar, N.A. (2014) Suitability Analysis of a New High School in the City of Calabasas. Doctoral Dissertation, California State University, Northridge.

[34] Saaty, T.L. (1980) The Analytic Hierarchy Process. McGraw Hill, New York, Reprinted by RWS Publication, Pittsburgh.

[35] Muthama, N.J., Masieyi, W.B., Okoola, R.E, Opere, A.O., Mukabana, J.R., Nyakwada, W., Aura, S., Chanzu, B.A. and Manene, M.M. (2012) Survey on the Utilization of Weather Information and Products for Selected Districts in Kenya. Journal of Meteorology and Related Sciences, 6, 51-58. https://doi.org/10.20987/jmrs.08.2012.605

[36] Ongoma, V., Guirong, T., Ogwang, B.A. and Ngarukiyimana, J.P. (2015) Diagnosis of Seasonal Rainfall Variability over East Africa: A Case Study of 2010-2011 Drought over Kenya. Pakistan Journal of Meteorology, 11, 13-21.

[37] Ranawake, A.L., Dahanayaka, N., Amarasingha, U.G.S., Rodrigo, W.D.R.J. and Rodrigo, U.T.D. (2012) Effect of Water Stress on Growth and Yield of Mung Bean ( Vignaradiata L). Tropical Agricultural Research and Extension, 14, No. 4. https://doi.org/10.4038/tare.v14i4.4851 